\title{
Understanding 1 Timothy 3:1-7 and the need for righteous church overseers in Nigerian Christendom
}

\begin{tabular}{|c|c|}
\hline $\begin{array}{l}\text { Author: } \\
\text { Chidinma P. U }\end{array}$ & keachusim ${ }^{1,2}$ \\
\hline $\begin{array}{l}\text { Affiliations: } \\
{ }^{1} \text { Department } \\
\text { and Cultural S } \\
\text { the Social Scie } \\
\text { of Nigeria, NsL }\end{array}$ & $\begin{array}{l}\text { f Religion } \\
\text { udies, Faculty of } \\
\text { nces, University } \\
\text { kka, Nigeria }\end{array}$ \\
\hline $\begin{array}{l}{ }^{2} \text { Department } \\
\text { and Related Lit } \\
\text { of Theology an } \\
\text { University of P } \\
\text { South Africa }\end{array}$ & $\begin{array}{l}\text { f New Testament } \\
\text { erature, Faculty } \\
\text { d Religion, } \\
\text { etoria, Pretoria, }\end{array}$ \\
\hline $\begin{array}{l}\text { Research Proj } \\
\text { Project Leade } \\
\text { Project Numb }\end{array}$ & $\begin{array}{l}\text { ect Registration: } \\
\text { r: E. van Eck (D) } \\
\text { er: } 2400030\end{array}$ \\
\hline $\begin{array}{l}\text { Description: } \\
\text { Chidinma P. U } \\
\text { participating i } \\
\text { project 'Africa } \\
\text { NT Scholars', } \\
\text { Dr Ernest van } \\
\text { Department o } \\
\text { Testament an } \\
\text { Literature, Fa } \\
\text { Theology and } \\
\text { University of }\end{array}$ & $\begin{array}{l}\text { keachusim is } \\
\text { the research } \\
\text { Platform for } \\
\text { lirected by Prof. } \\
\text { Eck, } \\
\text { f New } \\
\text { Related } \\
\text { ulty of } \\
\text { Religion, } \\
\text { retoria. }\end{array}$ \\
\hline $\begin{array}{l}\text { Correspondin } \\
\text { Chidinma Uke } \\
\text { chidinmaukea } \\
\text { yahoo.com }\end{array}$ & $\begin{array}{l}\text { g author: } \\
\text { achusim, } \\
\text { chusim@ }\end{array}$ \\
\hline $\begin{array}{l}\text { Dates: } \\
\text { Received: } 08 \\
\text { Accepted: } 23 \\
\text { Published: } 14\end{array}$ & $\begin{array}{l}\text { ct. } 2020 \\
\text { =eb. } 2021 \\
\text { June } 2021\end{array}$ \\
\hline $\begin{array}{l}\text { How to cite th } \\
\text { Ukeachusim, } \\
\text { 'Understandin } \\
3: 1-7 \text { and the } \\
\text { righteous chur } \\
\text { in Nigerian Ch } \\
\text { HTS Teologies } \\
\text { Theological St } \\
77(1) \text {, a6350. } \\
\text { org/10.4102/ }\end{array}$ & $\begin{array}{l}\text { is article: } \\
\text { C.P., 2021, } \\
\text { g } 1 \text { Timothy } \\
\text { need for } \\
\text { ch overseers } \\
\text { ristendom', } \\
\text { Studies/ } \\
\text { udies } \\
\text { https://doi. } \\
\text { tts.v77i1.6350 }\end{array}$ \\
\hline Read online: & \\
\hline 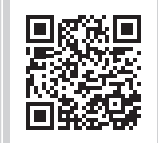 & $\begin{array}{l}\text { Scan this QR } \\
\text { code with your } \\
\text { smart phone or } \\
\text { mobile device } \\
\text { to read online. }\end{array}$ \\
\hline
\end{tabular}

Christianity is one of the main religions thriving in Nigeria as seen in the high rate of proliferations of churches and plenipotentiaries who claim to be divinely called to establish and oversee their churches. The need for righteous church overseers cannot be overemphasised. The effects of unrighteous leaderships in most churches are negatively impacting the holistic mission-mandate of the church in Nigeria. This article focuses on exegetically exploring, interpreting and applying the context of 1 Timothy 3:1-7 to the church's leadership situation in Nigeria. Exegetical approach is used to establish the diachronic and theological influences that motivated Paul to advise Timothy about the qualifications of a plenipotentiary of God who is to be admitted to the office of an overseer, and how overseers are to conduct themselves in the house of God. The world of the early Christians can be compared with the world of Christians of the 21st century. Then as now, there are those who desire to be church overseers, but whose character and doctrines deny the fundamental principles of the church. This article argues that the categorical instructions of Paul to Timothy about the qualifications of overseers are still relevant for the church in Nigeria to be led in righteousness.

Contribution: This study fits the scope of this journal as it addressed the theological implications of the proliferation of church-overseers who refrain from adhering to the bishopric criteria enlisted by Paul. It recommended exegetical-solutions on how the Nigerian church leaders are to be righteous bishops as underlined in 1 Timothy 3:1-7.

Keywords: church; righteous leadership; 1 Timothy; bishop; Christendom; Nigeria.

\section{Introduction}

The church is the body of Christ on earth. Jesus Christ is the founder, the head and from his Spirit proceeds the force behind the mission-mandate of the church. Although Jesus is the head of the church, he uses human beings to physically lead and oversee the administration of the church. The Trinity, although being in charge of the mission-mandate, has entrusted the pastoral responsibilities to the leadership of the church (Keathley 2004:1). The church has members who are to be led and guided in righteousness as Jesus and his early apostles modelled. Every member of the body of Christ is called by God but bishops are specially ordained amongst others to shepherd (Merkle 2010:3), oversee the planting and administration of the church in every generation. Overseeing the church's affairs in righteousness is very crucial in carrying on and achieving the mission goals of the militant church in Nigeria.

It is a problem both in the body of Christ and in the entire society, when the church is not righteously overseen and the lives of the church overseers are not commensurable to the leadership qualifications as stipulated in the scriptures. A preponderance of Nigerian Christians go into the business of planting churches and its overseeing for selfish reasons (Elo 2018:1) and these have continued to threaten the holistic mission-mandate of the church in Nigeria.

Bishopric is not an easy undertaking. In this era, there are many who desire to be in church leadership at all cost (Awojobi 2015:1). Paul who was divinely called into the ministry, by virtue of his wealth of experiences, laid out the leadership qualifications expected of those who are called or who desire to serve God as bishops in the church. Paul gave so many instructions to Timothy and Titus about the selection of church leaders (Tt 5:16; 1 Tm 3:1-7). These Pauline instructions might be called critical concerns for pastoral ministry because they address matters that are tremendously important to the leaders themselves and to the well-being of the flock of God as a whole (Keathley 2004:1).

Copyright: (C) 2021. The Authors. Licensee: AOSIS. This work is licensed under the Creative Commons Attribution License. Note: Special Collection: Africa Platform for NT Scholars, sub-edited by Ernest van Eck (University of Pretoria). 
Paul as an experienced church planter and overseer wrote letters to Timothy and Titus to guide them in their pastoral works. In the context of 1 Timothy 3:1-7, Paul specifically instructed Timothy on the qualifications that anyone called or who desires to be an overseer must attain to be a righteous leader in the household of God. Paul instructed Timothy because he knew that although Timothy was sincere in his acts of service, nevertheless, that there are others who are in the ministry or who may desire to be in the ministry with ulterior motivations, who may turn heretic and mislead others. Consequently, Paul wrote to instruct Timothy on how he must conduct himself in his acts of services and the qualifications required from church bishops. These instructions given to Timothy are still relevant to be adhered to by those who are already bishops and those who desire to be bishops in the church. This study employed exegetical method of doing biblical criticism to examine the texts and to give and apply the interpretative and theological motif of the author of the texts being examined (Ituma 2016:107) to the church's leadership situation in Nigeria.

\section{Sitz im Leben of the context of 1 Timothy 3:1-7}

The author of the letters to Timothy is Paul, an apostle of Jesus who was divinely called, trained by the Holy Spirit and commissioned by the church leaders in Jerusalem. He was an inspired preacher, experienced church planter and overseer. Paul wrote letters to churches and to individuals who were church leaders. Titus received one pastoral epistle from Paul, but Timothy received two pastoral letters from Paul. Firstly, Timothy was the first epistle Paul wrote to a church leader he raised (1 Tm 1:1). Secondly, Timothy contains what Paul tells Timothy to do as they relate to the community problems (Brown 2014:656).

Timothy, the original recipient of 1 Timothy came from Lystra in Galatia. His father was of Greek origin, whilst his mother, Eunice, was of a Jewish origin (Ac 16:1-3). It was Paul who probably led Timothy and his mother and grandmother to faith in Jesus. Timothy joined Paul on his second missionary journey. Paul groomed Timothy in his ministry, hence he described Timothy as 'a true son in the Faith' (1 Tm 1:2) (Guzik 2015:2). Paul may have written this letter between 63 and 66 CE to Timothy for two reasons. Firstly, it served as a personal encouragement to Timothy and secondly the letter could be used as a letter of reference before the Ephesian Christians (Guzik 2015:1), who were converted from paganism (Kizhakkeyll 2006:251). The letters were also intended 'to be read to the churches committed to the charge of Timothy' (Guzik 2015:2). Paul categorically instructed Timothy his protégé to charge some to teach no other doctrine (1 Tm 1:3). 1 Timothy contains specific instructions on how Timothy who was asked to become the bishop or overseer

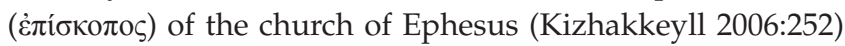
and other church bishops are to righteously conduct themselves in the house of God and on how to fight the good fight of faith (1 Tm 1:18) (Kranz 2013:2). These instructions are important and ever relevant because 'in Paul's mind sound doctrine and right conduct are vitally connected. Sinful actions are contrary to sound doctrine' (Guzik 2015:7). One of the results of Paul's second missionary journey was the planting of the church at Ephesus (Ac 18:19) (Caruso 2015:3). Timothy accompanied him to Ephesus (1 Tm 1:3). Paul left Timothy at Ephesus to govern the Ephesians church and to provide a sound leadership model. The early church as of then has started to experience issues of false teachers and false teachings. Paul was certain that Timothy being young in the ministry would surely encounter and deal with redirecting the parts of the heretics. Nevertheless, Paul wanted Timothy to remain in Ephesus and continue the work whilst he would be in Macedonia. To further guide him, Paul wrote 1 Timothy as a follow-up letter from Philippi in Macedonia. In this follow-up letter, 'Paul warns Timothy about false teachings and advises him about Christian worship and church administration' (Taylor 2020:2). Paul's letter to Timothy consolidates sound doctrine and godliness. It is in 1 Timothy 3:14-15 that Paul categorically declared why he wrote those instructions to Timothy. Although he had planned to visit Timothy and the church, he thought it unnecessary to delay writing to guide Timothy.

\section{Exegesis of 1 Timothy 3:1-7}

Paul values his instruction as $\pi \iota \tau$ ò $\varsigma$ - a faithful saying for the church. In this pericope, Paul consolidates that leadership in the church of God is not an office that is equivalent to other leadership positions in secular governments. The church is a unique fold; hence, the criteria for church's leadership differ from those that are found within the secular governments. The uniqueness of the divinely instituted church and its style of leadership are God's idea (eds. Platt, Akin \& Merid 2013:5). Consequently, bishopric is not a human invention but an office of divine appointment. Bishopric is not merely a good preferment that confers great honours and advantages. The office of a bishop is inherently characterised with work that requires God's calling and diligence to execute. A bishop is in charge of the spiritual life and administration of a particular church, diocese or ecclesiastical province. A church overseer leads and teaches (Merkle 2003:221). Amongst many criteria which people meet up to assume leadership roles, Paul gives a trustworthy ( $\pi$ $\sigma \tau$ ò $)$ criterion which anyone who desires the office of an overseer must adhere to in order to righteously oversee any category of assembly in the household of God.

Paul in all his pastoral epistles used the phrase 'this is a faithful saying and worthy of all acceptance' five times to introduce a statement of special importance to his theological instructions (Guzik 2015:9). Those who go into secular leaderships may have varied terms of leadership; nevertheless, Paul in 1 Timothy 3:1 makes a statement he

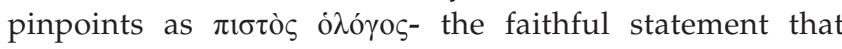
reveals how church overseers must conduct themselves in their servanthood leadership over the shepherds. Paul categorically declares that the instruction he articulated

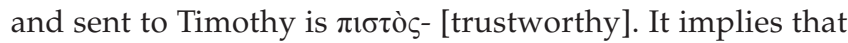


there were other statements or leadership actions which he perceives to be unfaithful and hence not trustworthy. There may have been so many wrong motivations for which many aspire to be church overseers for which Paul warns Timothy against (1 Tm 1:6-7). Paul may have been acquainted with the teachings of Jesus on leadership. It could also be that the Holy Spirit imbibed in him the criteria of being a righteous leader, and hence he was able to describe what he through writing communicated to Timothy as being 'trustworthy'. Being inspired, Paul through writing gave to Timothy trustworthy criteria which anyone who desires

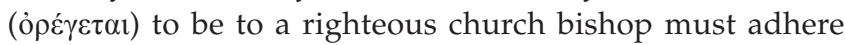
to. The office of an overseer has everything to do with leading in righteousness which is consolidated in agape kind of love which emanates from a pure heart, a good conscience and from a sincere faith in Jesus $(1 \mathrm{Tm} 1: 5,19)$. It embodies being a servant as Jesus taught about righteous leaderships (Mk 10:25-45; Jn 13:1-17). To aspire the office of a bishop is not a problem for Paul, for he judges it to be

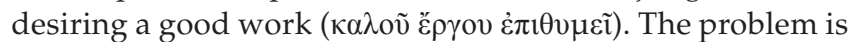
located in being able to accept and adhere to the criteria that are supposed to characterise a righteous bishop.

Episkopos - 'to oversee'- could literally mean 'to-see-over' or 'to-watch-over'. Bishops do the enormous work of overseeing the churches under them. They are those who are responsible to lead the church (MacArthur 2001:41), in both spiritual and administrative areas (Swindoll 2010:20). Desiring 'to oversee' is adjudged to be good because it has to do with watching over, identifying and servicing that which needs to be serviced in the household of God (Dickson 2010:1607). The theological concern lies in the motivation for which one desires 'to oversee' the household of God. In the church, the emphasis on leadership is on 'servanthood' and not on position. It has to do with work and not just honour. It is only those who have sincere and righteous motivations to desire to see over the needs in the household of God and be inspired to make right moves to solve them are the ones that desire good works.

Paul's list of the criteria of being a bishop focuses on the nature of the behaviours expected from the person and the family of the prospective church overseer. Paul in verse 2 of 1 Timothy 3 starts enlisting categorically that anyone who desires to be a bishop in the household of God must 'be

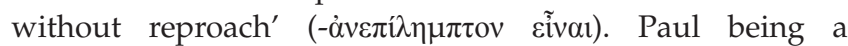
passionate church planter and overseer declares that for one to be a church overseer, the person must be 'blameless'. The overseer must daily live a life that is free of criticism

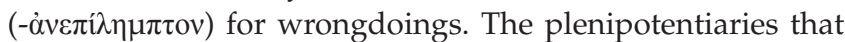
defy theological ethics, who secretly indulge in immoral actions, incur shame to themselves and to their families. Also, the reproaches they incur extend to their acclaimed ministries and to the mission-mandate of the church. Paul being cognitive of the consequences of the lifestyle of an overseer incurring reproach to the church advances that an overseer

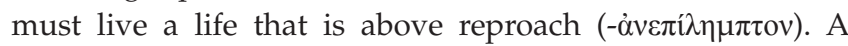
higher standard is required of office-bearers in the body of Christ (eds. Black \& Rowley 1972:1003). It is by adhering to the theological leadership dictates that a plenipotentiary can be a righteous leader.

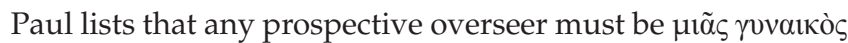
¿ $v \delta \rho \alpha$ [a husband of one wife]. Paul is knowledgeable of the dangers associated with church overseers not having control over their sexual desires. Consequently, Paul stresses that it is necessary that the prospective church overseer must be monogamous, that is, being married to only one woman (Andria 2006:1499), and who continues to live in faithfulness and harmony with this same woman (Swindoll 2010:22). The unspoken part of what Paul may have implied revolves around the sexual immoralities some unmarried and married plenipotentiaries of God may be vulnerable to. Anyone who desires to be an overseer must not be associated with sexual immoralities. Therefore, Paul categorically instructs Timothy that anyone who desires to occupy the office of an overseer must 'marry one wife' so that he can be meeting his sexual needs within the confines of his marriage. In addition to being a husband of one wife, other essential qualifications of the church overseer include that he has to be sober, self-controlled, prudent and hospitable. He must be able to teach (Stott 1996:6) his family and others righteously.

Paul also enlists that any prospective church overseer must

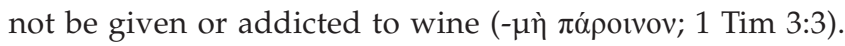
The scriptures contain many instances where being given to wine and being addicted to wine have influenced many in leadership positions to pervert judgements. The influence of wine has led so many astray and they found themselves doing what they should not have done if they were not under the influence of wine. Then after conversion, many early Christians were still given to wine and some still being addicted to wine. Being drunken, they performed acts that bought shame and reproach to them. Paul may have become prompted to include it amongst what a responsible church overseer must not be guilty of. For Paul, anyone who desires to occupy the office of an overseer is not to be filled with wine, rather he is to be filled with the Holy Spirit (Eph 5:18).

Again, Paul enlists that the prospective overseer should 'not

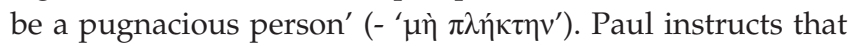
anyone who desires to be a bishop must not be aggressive in his relationship with people in and outside the church. Against being belligerent, Paul advances that a prospective bishop should be gentle (- $\dot{\pi} \imath \varepsilon 1 \kappa \tilde{\eta})$. He must be peaceable

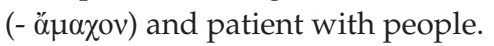

Furthermore, Paul enlists that the prospective bishop must

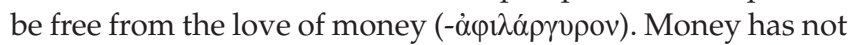
been the problem, rather it is the love of money that is the root of evils in the world (1 Tm 6:10). It is recurrent that when people are driven by the love of money, their conscience will be dead to love people sincerely. Those whose love for money becomes their god err from their faith in Jesus. Paul being cognitive of the destructive power of the love for money listed it amongst what should not characterise a prospective church overseer. 


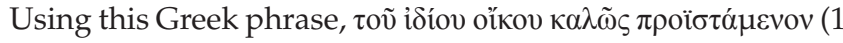
Tm 3:4), Paul enlists that a prospective overseer must manage his family well. He should be capable of keeping his children submissive in all dignity. Family is an important unit both in the church and the society at large. If family units are not managed well, the incurred undesirable implications are felt both in the church and in the larger societies. In this pericope, $\pi \rho 0 і ̈ \sigma \tau \dot{\alpha} \mu \varepsilon v o v$ is used in its verb participle present middle accusative masculine singular form. Проїбт́́ $\mu \varepsilon v o v$ denotes 'must'. Paul implies that the prospective overseer must continue to rule and manage his household well in all dignity subjecting them under obedience to God. Church leaders who relent in taking seriously their parenting responsibilities may incur grave consequences for neglecting their parenting responsibilities (Judd 2001:3). During the 1st century era, there may have been many converts, who were not with all

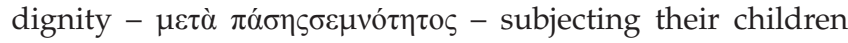

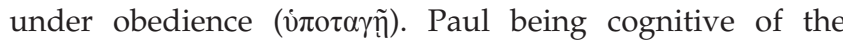
dangerous effects of a man who cannot in dignity manage his family being made an overseer in the church of God instructs Timothy against such being selected to occupy the office of a superintendent in the household of God.

In verse 5, Paul uses a rhetoric question to explain why the prospective church overseer is required to be capable of managing his household before he is qualified to oversee the

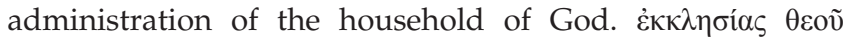
(1 Tm 3:5) is used in its singular common feminine genitive noun form. Family system can be compared with the household of God. Paul knows the all-encompassing implications of anyone who cannot control himself, and who cannot with all dignity rule his family serving as an overseer in the household of God. In this verse غ̇ $\pi 1 \mu \varepsilon \lambda \eta ́ \sigma \varepsilon \tau \alpha l$ - 'to care for' is used in its future tense. The ability of the prospective bishop to, in the future, care for God's church lies first in his ability to take care of his own family. Following this, Paul stresses that an overseer must be subjecting his family in obedience to God. It is only then that the overseer would be

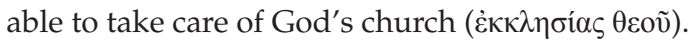

Again, Paul enlists that anyone who desires to be a bishop

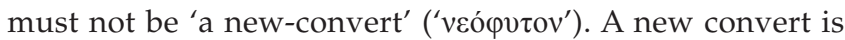
one who is newly converted to Christian faith. Paul describes 'new-converts' as babies that are to be fed with the sincerely milk of the word of God (James 2016:2). New converts are those who are to be taught the basics of Christian teachings, and they are not to take up leadership positions in the church because they are still immature. If the new-converts are misinformed, they could backslide or turn heretic. At their immaturity level, with given leadership positions, they might become proud and fall. New-converts who are leaders could mislead others. Paul being cognitive of the effects of appointing new-converts to leadership positions in church administration instructs that a newconvert must not be allowed to serve in the church as a bishop.

Lastly, Paul enlists that the prospective bishop must have a

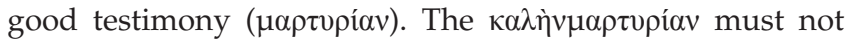

only come from those inside the church but also from the outsiders, $\check{\varepsilon} \xi \omega \theta \varepsilon v(1 \mathrm{Tm} 3: 7)$. The outsiders refer to those who are not members or are yet to be converted to the church of

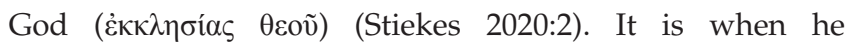
consolidates a healthy relationship with everyone that he would get good reports. If he does not behave and keep good relationship with people inside and outside the church, his bad behaviour would incur reproach to him and to the body of Christ. Devil is the enemy of Christ, his body, the church and the accuser of the brethren. Tirelessly, the Devil plans to entrap the followers of Jesus in sin to disgrace, destroy the sinner and reproach the body of Christ. Paul being aware of

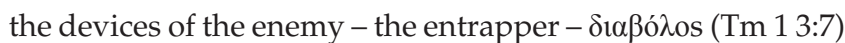
instructs that anyone who aspires to be a bishop must have good reputation.

\section{Conclusion on exegesis of 1 Timothy 3:1-7}

The instruction of Paul to Timothy on how anyone who desires to be a bishop must behave is valued to be trustworthy. Paul's church leadership qualification 'checklist' (Swindoll 2010:24) contains criteria which a prospective bishop must adhere to in order to be a righteous overseer of any category of the assembly in the body of Christ. Being that there will continue to exist the need to have the office of the overseers who would 'oversee' the administrations of the church, Paul was inspired to write to Timothy instructions he valued to be indispensable qualifications that anyone desiring to be a righteous church overseer must abide by. These instructions are not peculiar to Timothy and the 1st century prospective church overseers. Although Paul instructed Timothy in this context, the instruction is still trustworthy for anyone who desires to be a righteous church overseer in every age.

\section{The theological implications of church founders and overseers not adhering to theological leadership instructions in 1 Timothy 3:1-7 in Nigerian Christendom}

Failing to adhere to theological leadership criteria by many church founders, overseers are exerting negative effects on the holistic mission-mandate of the church in Nigeria. Applying Paul's qualifications of a righteous church leader to church leadership situations in Nigerian Christendom, it is glaring that many applauded church leaders in Nigeria are not qualified to join in the ministry as church overseers. Listed and explained below are the characteristics of a preponderance of church bishops in Nigeria.

\section{Wrong motivated desire to be bishops}

Motive is the psychological feature that arouses a person to act towards achieving a desired goal. It gives purpose and direction to the behaviour of the person who takes the action (Siroki 2019: 1). Motivation for taking a defined action could be either wrong or right. So many church leaders are motivated by selfish reasons (Iheanacho 2009:1). Because of 
selfish motivations, church commercialisation has become one of the phenomena in the Nigerian Christendom (Princewell 2017:1). Paul in the context of 1 Timothy 3:1-7 stresses that anyone who desires to be an overseer in the household of God desires a noble work. But in Nigeria, a significant number of those who aspired to be church overseers establish churches which they are overseeing being wrongly motivated and this has negatively resulted in the proliferation of autonomous and non-centralised churches (Essien 2010:649). Theologically, to have churches planted and overseen based on wrong motivation is a besetting turpitude.

Many see and undertake the churches they have established and oversee as their family business from which they must achieve their clandestine goals (Elo 2018:1). The churches are administered as their family business from which they enrich themselves with resources to do as they wish (Falako \& Facsar 2018:1). Church overseers in Nigeria as church owners (Vaters 2017:1) compete with themselves in building gigantic church auditoriums, schools, banks and many other uncountable businesses and ventures, yet they ask the church members to contribute to their personal businesses (Ibeabuchi 2012:2). Theologically, a church is not to be managed as a family business (Vaters 2017:1) where church founders can easily accumulate wealth from the solution oriented who would do anything to buy hope (lbeabuchi 2012:2). Wrong motivation makes a preponderance of church founders and plenipotentiaries to venture into church planting and its overseeing as a business venture. Wrong motivations and passion hinder the spread of the gospel. Being that a preponderance of church founders and leaders establish and run their churches based on wrong motivations, its consequences have been negatively impacting the holistic mission-mandate of the church in Nigeria (Ukeachusim, Ezichi \& Uroko 2021:372).

\section{Many acclaimed church planters and overseers incur reproach to the church}

Many applauded church planters and overseers live lives that earn reproach to themselves and to the body of Christ at large. Daily, there are upsetting stories of some plenipotentiaries of God engaging in illicit sexual affairs and occult practice. The menace keeps rearing its ugly head in different forms. This is aside other alarming activities as ritual killings and 419 (Okoh 2019:1). As a consequence of their blameworthy character, some church bishops have had their personalities tarnished and also dented the image of the church to the outsiders. In Nigeria, some celebrated church founders and overseers are toxic church leaders. They are figuratively poisonous to the churches they are overseeing. Toxic church leaders lack transparency; they are selfabsorbed and are not accountable to anyone; they show favouritism; they perceive themselves to be superior to others; they marginalise and manipulate the needy, the poor and the gullible people; and they have the habits of surrounding themselves with sycophants who are 'oh yes members' (Rainer 2014:1). Consequently, many who are into church leadership positions do not love God. They are in the ministry for their ulterior reasons. In Nigeria, the toxic leaders are not few and they appear to be charismatic and manipulative. In secret, they commit awful atrocities like rape (Ukpong 2020:1), money laundering (Odunsi 2020:1), fake miracles (Hanafi 2020:1), rituals (Edem 2017:3) within the churches they are overseeing. Because of their toxic nature, some insiders and outsiders adjudge their way of life and leadership strategies to be evil, and hence they view them as being blameworthy.

\section{A preponderance of church leaders indulge in sexual sins}

In Nigeria, some applauded married and unmarried mainline priests and Pentecostal church overseers secretly indulge in sexual sins or misbehaviours. Although 'the church is supposed to be the strong moral institution' (Okoh 2019:5), many of them live a licentious life. Onaiyekan (2019:3) confessed that 'recently, we have been dealing with cases of high level Catholic leaders that were found wanting in this regards'. Secretly, some church overseers and leaders are gays (Okafor 2020:1), paedophiles (Per Second News 2020:1), fornicators and adulterers (Augoye 2019:1); some are addicted to pornography whilst they are still being applauded as plenipotentiaries of God who were divinely called to oversee churches or a local assembly. There are many cases of church overseers raping their church members (Famuyiwa 2019:1). Their victims live in pain whilst some weak Christians are led astray. Because it is natural for church leaders and overseers to have sexual needs, Paul instructs that the righteous church overseer must be a faithful (Swindoll 2010:22) husband of one wife (Andria 2006:1499) so that within the confines of his marriage, the bishop can be righteously satisfying his sexual desires without attracting reproach to himself and to the church. But in Nigeria, some self-styled church overseers use marriage to one wife as a cover to be committing diverse kinds of sexual sins. The reproach they incur exacts negative impacts on the holistic mission-mandate of the church in Nigeria.

\section{Many church overseers are given to wine and some are addicted to wine}

The church is instituted and consolidated to be the highest moral institution spearheaded by divinely inspired moral leaders. In Nigeria, many pastors, church founders and overseers have erred through wine and through intoxicating drink, hence they err in vision and stumble in judgement (Is 28:7) (Aribisala 2018:2). Paul advances that the true followers of Christ are to be filled with the Holy Spirit (Eph 5:18) because he is the person that empowers Christians to be victorious. But in Nigerian Christendom, many church leaders are given to wine (Johnson 2020:1) and some are addicted to wine (Newsexpress 2017:9). Churches are divided on whether pastors and the laity are to consume alcohol (Udodiong 2019:7). Being given or addicted to wine predisposes them to pervert judgement. 


\section{Many church overseers are pugnacious leaders}

Many of the acclaimed plenipotentiaries of God in Nigeria are belligerent and arrogant. In being pugnacious and arrogant, some curse and hurl invective against other church leaders or followers who provoke them (Ugbodaga 2020:1). Some engage in open confrontation and physical combats (Ososanya 2020:1). Some invite police to broker peace during leadership tussles and conflicts (Adebowale 2016:25). There are still others who take their matters to the court (Akinloye 2019:1). To get what they want for their selfish desires, they curse their followers if they relent in giving offerings, tithes, donations, seed faith, first fruits, partnership giving, etc. (Saharareporters 2018:2). Church politics reveals their pugnacious nature. Their belligerent nature incurs reproach to their person and to the holistic course of the missionmandate of the church. Paul knew about the negative effects of church overseers being contentious. Consequently, Paul instructed Timothy that anyone who desires to be an overseer of any assembly of the church must not be an aggressive person.

\section{Lovers of money}

Many churches are falling apart because many strains of church leaders in Nigeria are following the pattern of desperately seeking for opportunities to amass wealth to build their own empires. For some church leaders to consolidate their church empires, even if God does not call their children, they call their children into the ministry themselves (Elo 2018:1), whilst some others make their children board members and groom them to be able to succeed them. A significant number of church leaders desired to be in church leadership and so many are already in church administration because of their covert love for money (Agunbiade 2018:3). Many who succeeded in becoming church founders and overseers in Nigeria are observed to be occupied with generating new ways of sourcing money from their members, audiences and followers with which they could build their own empires. They use manipulative means to be accessing monetary assistance from their members (Saharareporters 2018:3). They create church activities through which offerings, tithes, seed faiths, first fruits, partnership offerings and donations will continually be generated for them to keep enlarging their thriving business empires (Falako \& Facsar 2018:1). They are overly interested in erecting big worship centres, owning private jets, building business empires like banks, housing estates and schools (Cocks 2014:3), and flaunting costly wears (Ajasa 2018:1). They are intrinsically autocratic leaders who are not accountable to any authority. They show characteristics of losing focus on the mission-mandate of the church. They are not passionate about learning from Jesus Christ who is the Lord of the church and from the early apostles who were the first set of the church overseers. It is this leadership attitude that Paul condemned by instructing that anyone who desires the office of a bishop must not be a lover of money. This is instructed because both in the secular world and in the household of God it is the love of money that is the root of all evils. Many who desire to occupy the office of the overseers in the household of God in
Nigeria are guilty of being motivated by their clandestine love for money (Nwadialor \& Umeanolue 2013:1).

\section{Many church founders, overseers and leaders are new-converts}

In Nigeria, some who are church leaders and overseers are new-converts, whilst some are not Christians (Elo 2018:3). These half-baked Christians or those who are not Christians got themselves into planting and overseeing churches because it has been rated as one of the quickest ways to become wealthy in Nigeria (Oyelade 2009:1). For diverse motivations, some new or superficial converts work their way to plant churches whilst lacking the theological qualifications of being a church overseer. Most of these church founders and overseers act like chief executive officers marketing Jesus as their product (Vaters 2017:1). Because some of them learn the art of being charismatic, charming and manipulative, they seem to be excelling in their applauded ministries. Many church overseers in Nigeria thrive in giving prophesies and in performing acclaimed signs, wonders and miracles. In manifesting their acclaimed gifts of the Spirit and having their applauded results, many of them tend to become proud. But because of the material things they have envisaged to get from being church founders and overseers, they go against the leading of the Holy Spirit to become self-styled church bishops. This has resulted in the proliferation of churches and those who claim to be mandated by God to plant and oversee churches in Nigeria. Paul therefore enlists that those who are new-converts to Christian faith should not be allowed to serve God in the office of a bishop.

\section{Many bishops are not apt to teach}

A preponderance of church founders and overseers in Nigeria are not apt to teach and preach the gospel, shepherd and govern the church in righteousness, rather they covet this vocation because of the influence and affluence it promises (Ogienagbon 2020:2). Many of the celebrated church overseers teach sermons that are not entirely the gospel of Christ (Ayankeye 2019:1). They show charisma in preaching on prosperity and health gospels, motivational talks and prophesies (SaharaReporters 2019:3). They shy away from the main mission-mandate goals which are consolidated in the gospel commission (Mt 28:16-20) (Amaechina 2019:1). Observing the modus operandi of most self-styled church founders and overseers in Nigeria, it is seen glaringly that they are not overseeing the church as Jesus and his early apostles modelled.

\section{Lessons and recommendations}

- In Nigeria, many acclaimed Christians see participating in church leadership as a do-or-die affair. It is therefore recommended that Nigerian Christians who desire to be bishops and those who are already bishops should constantly evaluate their motivations for desiring to be overseers in the church of God.

- For Nigeria to be effectively evangelised, church overseers should strive to be blameless. It is recommended that 
good reports from God, their immediate families, those inside the church and those outside the church are required from those who desire to be righteous church overseers in Nigeria.

- It is recommended that those who desire or who are already church overseers in Nigeria should be disciplined and have self-control so as not to incur reproach to themselves and to the mission-mandate of the church.

- Church overseers in Nigeria should strive to be able to manage their families very well. For it is in being able to manage their families' affairs that they can manage the church affairs well.

- Nigerian Christians who are to serve as overseers in the church must be matured in Christian faith. Those who desire to be church overseer must not be new-converts so that they will not become proud and mislead others.

- Plenipotentiaries of God who are qualified to oversee churches whether in episcopal or local assemblies in Nigeria should be those who have been trained and appointed by the Holy Spirit, and who are thereby equipped to teach others.

- Plenipotentiaries of God should engage in the missionmandate of the church being motivated by love from a pure heart, from a good conscience and from a sincere faith in Jesus.

\section{Conclusion}

The church of God like the secular world always has leadership needs. But church governments are not to be like the secular politics and governments. There are righteous leadership criteria which those who aspire to be diocesan bishops or local church overseers must adhere to in order to lead in righteousness. Paul, an experienced church planter and overseer, being cognitive of the implications of the unqualified being given the post of church overseer instructed Timothy to watch out for the leadership criteria he listed before appointing anyone to take the bishop position in church leadership. Although Paul's leadership instructions were given during the 1st century era, these leadership criteria are still very relevant to be adhered to by those who are called or who desire to serve in the household of God as overseers. It is based on these theological leadership qualifications that most Nigerian church leaders or overseers have been compared with and found lacking.

Nigeria is a religious country in which Christian faith is thriving; hence, there is a persistent proliferation of churches and those who claim to be divinely called to establish and oversee their churches. A significant number of these acclaimed church founders and overseers do not adhere to the theological criteria of being a bishop in the body of Christ as laid down in 1 Timothy 3:1-7. Many who are not qualified to be church overseers have been wrongly motivated to go into planting and overseeing churches and these have consolidated negative implications on the holistic missionmandate of the church in Nigeria. For the leadership needs of the church of God in Nigeria to be set on the righteous path, there is the need for those who are church overseers or those who are still desiring to be church overseers to adhere to the theological dictates on church leadership.

\section{Acknowledgements Competing interests}

The author declares that they have no financial or personal relationships that may have inappropriately influenced them in writing this article.

\section{Author's contributions}

C.P.U. is the sole author of this research article.

\section{Ethical considerations}

This article followed all ethical standards for research without direct contact with human or animal subjects.

\section{Funding information}

This research received no specific grant from any funding agency in the public, commercial or not-for-profit sectors.

\section{Data availability}

Data sharing is not applicable to this article as no new data were created or analysed in this study.

\section{Disclaimer}

The views and opinions expressed in this article are those of the author and not necessarily reflect the official policy or position of any affiliated agency of the author.

\section{References}

Adebowale, S., 2016, 'Forgery: Police forward assemblies of God's general superintendent's case file to Director of Public Prosecution (DPP)', The Eagle, 12 September, viewed 15 September 2020, from https://theeagleonline.com.ng/forgery-police-forwardassemblies-of-gods-general-superintendents-case-file-to-dpp/.

Agunbiade, G., 2018, 'Love of money, fame derail modern churches - Rev. Solomon Afolabi', Independent Newspapers, 08 July, viewed 04 August 2013, from https:// www.independent.ng/love-of-money-fame-derail-modern-churches-rev-solomon/.

Ajasa, F., 2018, 'Meet Nigeria's "designer pastors" changing ways we look at Christianity', The News Guru, 29 April, viewed 13 September 2020, from https://
thenewsguru.com/lifestyle/meet-nigerians-designer-pastors-changing-ways-wethenewsguru.com/life
look-at-christianity/.

Akinloye, I.A., 2019, 'Human flourishing, church leadership and legal disputes in Nigerian churches', in M. Green (ed.), Religion and human flourishing in Africa, pp. 25-41, Congerence-RAP, Stellenbosch.

Amaechina, O., 2019, From the mission President-AFRI Mission Evanet, viewed 15 September 2020, from http://www.afrimissionevanet.org/about-us/from-themission-president/.

Andria, S., 2006, '1 Timothy', in T. Adeyemo (ed.), Africa Bible Commentary, p. 1495, Word Alive, Nairobi.

Aribisala, F., 2018, 'Drunk pastors', Vanguard: Article of faith, 18 November, viewed 04 August 2020, from https://www.vanguardngr.com/2018/11/drunk-pastors/amp/.

Augoye, J., 2019, 'Nigeria: Popular Abuja Pastor confesses to committing adultery' Premium Times, 04 March, viewed 13 June 2020, from https://allafrica.com/ stories/201903050040.html.

Awojobi, P.O., 2015, Leadership conflict in the Nigerian church, viewed 15 August 2020, from https://www.biblicaltheology.com/Research/AwojobiPO01.pdf.

Ayankeye, O., 2019, 'Churches in Nigeria have failed in preaching undiluted gospelCleric', Pulse Nigeria, 02 September, viewed 15 September 2020, from https:// www pulse ng/communities/religion/churches-in-nigeria-have-failed-inpreaching-undiluted-gospel-cleric/edw79f8.amp.

Black, M. \& Rowley, H.H. (eds.), 1972, Peake's commentary on the Bible, p. 1003 Thomas-Nelson, Aylesbury-Bucks.

Brown, R.E., 2014, An introduction to the New Testament, p. 656, Theological Publications In India, Bangalore. 
Caruso, G., 2015, A brief biblical history of the church in Ephesus, viewed 10 September 2020, from https://kingsharbor.wordpress.com/2015/09/11/a-brief-biblical2020, from https://kingsharb
history-of-the-church-in-ephesus/.

Cocks, T., 2014, 'Nigeria's “Megachurches": A hidden pillar of Africa's top economy', Reuters, 11 October, viewed 15 September 2020, from https://www.reuters.com/ article/idUS91999914620141015.

Dickson, R.E., 2010, Dickson teacher's Bible with commentary and encyclopedic study guide, p. 1607, Africa International Mission, Hutchnson, KS.

Edem, E., 2017, 'Many churches are into ritual killings - Offiong Okon', Daily Post, 28 August, viewed 15 September 2020, from https://dailypost.ng/2017/08/28/ many-churches-ritual-killings-offiong-okon/.

Elo, D., 2018, 'Nigeria is a huge market for fake prophets because most people are gullible - Apostle Elo', Business Day, 12 August, viewed 15 September 2020, from http://businessday.ng/news-features/article/nigeria-huge-market-fake-prophetspeople-gullible-apostle-elo/.

Essien, A.M., 2010, 'Proliferation of churches: A leeway to commercialization of religion', European Journal of Scientific Research 45(4), 649-657.

Falako, F. \& Facsar, F., 2018, Nigerian Pentecostal mega churches: A booming business, 18 August, viewed 15 September 2020, from https://amp.dw.com/en/nigerianpentecostal-megachurches-a-booming-business/a-45535263.

Famuyiwa, D., 2019, 'Pastor confesses to raping church member, attempt to do money ritual', Pulse Nigeria, 20 November, viewed 17 September 2020, from https:// www.pulse.ng/news/local/pastor-confesses-to-raping-church-member-attemptto-do-money-ritual/Itcrjqy.

Guzik, D., 2015, 1 Timothy 1 - Fighting for the faith, 07 December, viewed 29 July 2020, from https://enduringword.com/bible-commentary/1-timothy-1/.

Hanafi, A., 2020, 'I regret being used by pastor Okafor, others to stage fake miracles Woman arrested for controversial healing', Punch, 14 March, viewed 18 September 2020, from http://punchng.com/i-regret-being-used-by-pastorokafor-others-to-stage-fake-miracles-woman-arrested-for-controversial-healing/.

Ibeabuchi, I., 2012, 'Nigeria: Churches-business or salvation?', The Foreign Report, 16 December, viewed 29 July 2020, from http://www.theforeignreport. com/2012/12/16/nigeria-churches-business-or-salvation/.

Iheanacho, N., 2009, 'A critical look at contemporary Nigerian Christianity', International Journal of Theology \& Reformed Tradition 1(3), 104-118, viewed 17 September 2020, from https://pdfs.semanticscholar.org/72b4/fdfd53e3214 c1687ed42af6111812be32682.pdf.

Ituma, E.A., 2016, Welcome to the New Testament writings, p. 107, Chinedum Publishers Ltd., Nsukka.

Johnson, V., 2020, 'Nigerian pastor shocks crowd, wins Guinness drinking competition' Guardian Life, 07 March, viewed 17 September 2020, from https://guardian.ng/life/ nigerian-pastor-shocks-crowd-wins-guinness-drinking-competition/\#: :text=A\%20 nigerian-pastor-shocks-crowd-wins-guinness-drinking-competition/\#: : $:$ text=A\%
Nigerian\%20pastor\%20has\%20left,up\%20by\%20Guinness\%20went\%20viral.

Judd, F., 2001, 'Eli and his sons: Some lessons for parents', Religious Educator 2(2), 47-51.

Keathley, H.J., 2004, Critical concern for Pastoral Ministry (1 Timothy1:3-7), viewed 28 July 2020, from https://bible.org/article/critical-concerns-pastoral-ministry-1timothy-13-7.

Kizhakkeyll, S., 2006, The Pauline epistles: An exegetical study, p. 251, Saint Pauls, Bandra.

Kranz, J., 2013, Timothy: The pastor's guide to sound teaching and godliness, viewed 01 August 2020, from https://overviewbible.com/1-timothy/.

Loveday, A., 2021, 'Are there any bishops in the Bible?', viewed 24 March 2021, from https://www.chester.ac.uk/sites/files/chester/Loveday's\%20Cathedral\%20 Lecture\%202012.pdf

MacArthur, J.F., 2001, 1 \& 2 Timothy, p. 41, Word-Publisher, Nashville, TN.

Merkel, B.L., 2003, 'Bishop', in C. Brand, C. Draper \& A. England (eds.), Holman illustrated Bible Dictionary, p. 221, Holman Reference, Nashville, TN.

News Express, 2017, 'Inside the Nigerian "Church" where worshippers are served alcohol during service', News Express, 15 October, viewed 17 September 2020 from https://Newsexpressngr.com/news/45039-inside-the-Nigerian-churchwhere-worshippers-are-served-alcohol-during-service.

Nwadialor, K.L. \& Umeanolue, I.L., 2013, 'Materialistic gospel message in contemporary Nigerian church: A critique', Journal of Religion and Human Relations 1(5), 1 viewed 15 September 2020, from https://www.ajol.info/index.php/jrhr/article/ view/105150.

Odunsi, W.M., 2020, 'Magu sleeps in my church to talk to God - Omale, pastor accused of money laundering', Daily Post Nigeria, 17 July, viewed 12 September 2020, from https://dailypost.ng/2020/07/17/magu-sleeps-in-my-church-to-talkto-god-omale-pastor-accused-of-money-laundering/.
Ogienagbon, L., 2020, 'Pastors and the Timothy creed', The Nation, 10 September, viewed 18 September 2020, from https://thenationonlineng.net/pastors-andthe-timothy-creed/.

Okafor, T., 2020, 'Pastor rapes 13-year-old-boy to cure homosexuality', Punch, 15 September, viewed 18 September 2020, from https://punching.com/pastorrapes-13-year-old-boy-cure-homosexuality/.

Okoh, N., 2019, 'Scandal in house of God: What church leadership must do', The Guardian Issues, 07 July, viewed 03 August 2020, from https://guardian.ng/issue/ scandal-in-house-of-god-what-church-leadership-must-do/.

Onaiyekan, J., 2019, 'Scandal in house of God: What church leadership must do', The Guardian Issues, 07 July, viewed 07 August 2013, from https://guardian.ng/issue/ scandal-in-house-of-god-what-church-leadership-must-do/.

Ososanya, T., 2020, 'Drama as pastor and his church members fight landlord during church service', Legit News, 23 August, viewed 09 August 2020, from https:// www.legit.ng/amp/1358975-drama-pastor-church-member-fight-landlordchurch-service.html.

Oyelade, B., 2009, 'Failed predictions 08: These men of God Goofed', Sunday Sun, 18 January, pp. 4-8.

Per Second News, 2020, 'Pedophile pastor rapes pastor's daughter', Per Second News, 04 August, viewed 17 September 2020, from https://persecondnews. com/2020/08/04/paedophile-pastor-rapes-pastors-daughter/amp/.

Platt, D., Akin, D.L. \& Merida, T. (eds.), 2013, Exalting Jesus in 1 \& 2 Timothy and Titus: Christ-centered exposition commentary, p. 5, B \& H Group, Nashville, TN.

Princewell, A., 2017, 'Church commercialization in Nigeria: Implications for public relations practice', Journal of Philosophy, Culture and Religion 28(1), viewed 13 September 2020, from https://core.ac.uk/download/pdf/234694856.pdf.

Rainer, T.S., 2014, Fourteen symptoms toxic church leaders, viewed 15 September 2020, from http://thomrainer.com/2014/10/fourteen-symptoms-toxic-churchleader/.

Ron B. 2015, 'What's the Milk and Meat of the Word?', viewed 24 March 2021, from http://www.scripturerevealed.com/the-church/whats-the-milk-and-meat-of-theword/\#: :text=In\%20conclusion\%2C\%20if\%20we\%20use,to\%20encourage $\% 20$ scattered\%20new\%20believers.

Sahara Reporters, 2018, 'Pastors use threat of curses to force church members to pay tithe bishop mike Okonkwo confesses', Sahara Reporters, 07 March, viewed 13 August 2020, from http://saharareporters.com/2018/03/07/pastors-use-threatcurses-force-church-members-pay-tithe-bishop-mike-okonkwo-confesses.

Sahara Reporters, 2019, 'Bakare explains why pastors get away with fake prophecies in Nigerian churches', Sahara Reporters, 14 July, viewed 10 June 2020, from http://saharareporters.com/2019/07/14/bakare-explains-why-pastors-get-awayfake-prophecies-nigerian-churches.

Siroki, S., 2019, Wrong motive, viewed 15 September 2020, from https:// christcenteredhouseofgod.org/wrong-motives.

Stiekes, G., 2020, Paul's instructions about 'outsiders' (part 1), viewed 15 September 2020, from https://seminary.bju.edu/theology-in-3d/pauls-instructions-about2020 , from https:
outsiders-part-1/.

Stott, J.R.W., 1996, The message of 1 Timothy and Titus (The Bible speaks today series), p. 6, IVP Academic, Downers Grove, IL.

Swindoll, C.R., 2010, Swindoll's New Testament insights on 1 \& 2 Timothy and Titus, p. 7, Zondervan, Grand Rapids, MI.

Taylor, C., 2020, Paul's 1st letter to Timothy in Ephesus, viewed 03 August 2020, from https://www.thebiblejourney.org/biblejourney1/16-Pauls-Letters-to-timothy-inephesus-titus-in-crete/pauls-1st-letter-to-timothy-in-ephesus/.

Udodiong, I., 2019, 'Is it a sin for pastors and Christian to consume alcohol?', Pulse Nigeria, 25 December, viewed 01 June 2020, from https://www.pulse.ng/lifestyle/ alcoholism-it-a-sin-for-pastors-and-christians-to-consume/cckqw39.

Ugbodaga, K., 2020, 'Four Nigerian pastors with shocking ungodly utterances', Pm News, 12 September, viewed 12 September 2020, from https://www. pmnewsnigeria.com/2020/09/10/four-nigerian-pastors-with-shocking-ungodlyutterances/.

Ukeachusim, C.P., Ituma, E.A. \&Uroko, F.C., 2021, 'Understanding compassion in Matthew (Matthew 14:13-21)', Theology Today 77(4), 372-392. https://doi org/10.1177/0040573620956712

Ukpong, C., 2020, 'Pastor arrested for allegedly raping 16-year-old girl inside church', Premium Times, 25 June, viewed 15 September 2020, from https://www. premiumtimesng.com/news/more-news/399676-pastor-arrested-for-allegedlyraping-16-year-old-girl-inside-church.html.

Vaters, K., 2017, 3 big problems with running a church like a business, viewed 28 May 2020, from https://www.christianitytoday.com/karl-vaters/2017/july/3-bigproblems-with-running-church-like-business.html. 